Correspondence Barbara E. Murray bem.asst@uth.tmc.edu

Received 2 February 2008

Revised 26 May 2008

Accepted 13 June 2008

\section{Identification and phenotypic characterization of a second collagen adhesin, Scm, and genome-based identification and analysis of 13 other predicted MSCRAMMs, including four distinct pilus loci, in Enterococcus faecium}

\author{
Jouko Sillanpää, ${ }^{1,2} †$ Sreedhar R. Nallapareddy, ${ }^{1,2} †$ Vittal P. Prakash, ${ }^{1,2}$ \\ Xiang Qin, ${ }^{3}$ Magnus Höök, ${ }^{4}$ George M. Weinstock ${ }^{3}$ and Barbara E. Murray ${ }^{1,2,5}$ \\ ${ }^{1}$ Division of Infectious Diseases, Department of Internal Medicine, University of Texas Medical \\ School, Houston, TX, USA \\ ${ }^{2}$ Center for the Study of Emerging and Re-emerging Pathogens, University of Texas Medical \\ School, Houston, TX, USA \\ ${ }^{3}$ Human Genome Sequencing Center, Baylor College of Medicine, Houston, TX, USA \\ ${ }^{4}$ Center for Extracellular Matrix Biology, Institute of Biosciences and Technology, Texas A\&M \\ University Health Science Center, Houston, TX, USA \\ ${ }^{5}$ Department of Microbiology and Molecular Genetics, University of Texas Medical School, Houston, \\ TX, USA
}

\begin{abstract}
Attention has recently been drawn to Enterococcus faecium because of an increasing number of nosocomial infections caused by this species and its resistance to multiple antibacterial agents. However, relatively little is known about the pathogenic determinants of this organism. We have previously identified a cell-wall-anchored collagen adhesin, Acm, produced by some isolates of $E$. faecium, and a secreted antigen, SagA, exhibiting broad-spectrum binding to extracellular matrix proteins. Here, we analysed the draft genome of strain TX0016 for potential microbial surface components recognizing adhesive matrix molecules (MSCRAMMs). Genome-based bioinformatics identified 22 predicted cell-wall-anchored E. faecium surface proteins (Fms), of which 15 (including $\mathrm{Acm}$ ) had characteristics typical of MSCRAMMs, including predicted folding into a modular architecture with multiple immunoglobulin-like domains. Functional characterization of one [Fms10; redesignated second collagen adhesin of E. faecium $(\mathrm{Scm})$ ] revealed that recombinant $\mathrm{Scm}_{65}$ (Aand B-domains) and $\mathrm{Scm}_{36}$ (A-domain) bound to collagen type $\mathrm{V}$ efficiently in a concentrationdependent manner, bound considerably less to collagen type I and fibrinogen, and differed from Acm in their binding specificities to collagen types IV and V. Results from far-UV circular dichroism measurements of recombinant $\mathrm{Scm}_{36}$ and of $\mathrm{Acm}_{37}$ indicated that these proteins were rich in $\beta$ sheets, supporting our folding predictions. Whole-cell ELISA and FACS analyses unambiguously demonstrated surface expression of Scm in most E. faecium isolates. Strikingly, 11 of the 15 predicted MSCRAMMs clustered in four loci, each with a class $\mathrm{C}$ sortase gene; nine of these showed similarity to Enterococcus faecalis Ebp pilus subunits and also contained motifs essential for pilus assembly. Antibodies against one of the predicted major pilus proteins, Fms9 (redesignated $\mathrm{EbpC}_{\mathrm{fm}}$ ), detected a 'ladder' pattern of high-molecular-mass protein bands in a Western blot analysis of cell surface extracts from $E$. faecium, suggesting that $\mathrm{EbpC}_{\mathrm{fm}}$ is polymerized into a pilus structure. Further analysis of the transcripts of the corresponding gene cluster indicated that $f m s 1$ $\left(e b p A_{f m}\right), f m s 5\left(e b p B_{f m}\right)$ and $e b p C_{f m}$ are co-transcribed, a result consistent with those for pilusencoding gene clusters of other Gram-positive bacteria. All 15 genes occurred frequently in 30 clinically derived diverse E. faecium isolates tested. The common occurrence of MSCRAMM- and pilus-encoding genes and the presence of a second collagen-binding protein may have important implications for our understanding of this emerging pathogen.
\end{abstract}




\section{INTRODUCTION}

Enterococcus faecium, a member of the normal commensal flora, has recently emerged as a prominent nosocomial pathogen that causes serious infections, including infective endocarditis (Murray, 2000). Nosocomial infections due to E. faecium can be a life-threatening challenge to physicians because of this organism's multi-drug resistance (Murray, 2000; Rice, 2001). Furthermore, in addition to the selective advantage conferred by antibiotics, strains that emerge in the hospital setting more often carry putative virulence genes such as esp, encoding enterococcal surface protein (Rice et al., 2003; Willems et al., 2001), hyl, encoding a putative hyaluronidase (Rice et al., 2003), and a functional copy of the acm gene, encoding a collagen adhesin (Nallapareddy et al., 2003, 2008a, b).

It is known that pathogenic bacteria have evolved a plethora of proteins to adhere to and invade host tissues and to resist host defences (Pizarro-Cerda \& Cossart, 2006). Among these is a family of surface proteins with well-established roles in host-pathogen adherence which have been termed microbial surface components recognizing adhesive matrix molecules (MSCRAMMs; Patti et al., 1994). MSCRAMMs share several characteristics, including (i) an N-terminal signal peptide, (ii) a non-repeated Adomain consisting of immunoglobulin (Ig)-like fold(s), (iii) a B-domain with a variable number of repeats among different strains, and (iv) a C-terminal cell wall anchor (CWA) domain. Some of these MSCRAMMs have been shown recently to be tethered to each other by a designated sortase to make up multimeric cell surface structures, named pili (Mora et al., 2005; Nallapareddy et al., 2006). Sortases, encoded by the srtA to srtD classes of genes (Dramsi et al., 2005), were originally described as membrane-bound transpeptidases that cleave the LPXTGlike motif in the CWA domain and covalently link CWA proteins to the peptidoglycan (Marraffini et al., 2006). While class A sortases appear to be ubiquitous and involved in cell surface anchoring of a large number of LPXTG-containing proteins (Marraffini et al., 2006), the class C (subfamily 3 ) sortase enzymes, which have a more

†These authors contributed equally to this work.

Abbrevaiations: $\mathrm{Cl}$, collagen type I; CIV, collagen type IV; CV, collagen type $\mathrm{V}$; CD, circular dichroism; CWA, cell wall anchor; ECM, extracellular matrix; HMM, high molecular mass; Ig, immunoglobulin; MSCRAMM, microbial surface components recognizing adhesive matrix molecule.

Supplementary methods, describing bacterial isolates, identification and structural analysis of CWA proteins, and sources of extracellular matrix proteins; supplementary results, describing sequence variation in $\mathrm{fms} 15$, fms 16 and $f m s 19$, and structural motifs of the putative E. faecium MSCRAMMs; supplementary references; three supplementary figures, showing Coomassie-stained SDS-PAGE results for purified recombinant His6-Scm proteins, analysis of Scm expression on the cell surface of $E$. faecium isolates, and conserved lysine and glutamic acid residues in the pilin motif and E-box of predicted E. faecium major pilus proteins; and a supplementary table, listing oligonucleotides used in this study, are available with the online version of this paper. limited substrate specificity, have recently been shown to be involved in pilus biogenesis, in addition to their role in surface anchoring (Kemp et al., 2007; Scott \& Zahner, 2006; Telford et al., 2006).

Studies that have characterized the binding interactions of staphylococcal and enterococcal MSCRAMMs have identified that the ligand-binding A-domains consist of two to three subdomains (N1-N2/N3), each adopting an Ig-like fold (Liu et al., 2007; Nallapareddy et al., 2007; Ponnuraj et al., 2003; Zong et al., 2005). Based on the crystal structures of prototype MSCRAMMs, two slightly different models have been proposed to explain their binding mechanisms to linear peptides of fibrinogen and to triple-helical collagen. In the 'dock, lock and latch' binding model, a fibrinogen chain is inserted into a cleft between two Igfolded subdomains and is then secured by a C-terminal N3 extension (latch) that is reoriented upon ligand binding and complements a $\beta$-sheet on the N2 subdomain (Ponnuraj et al., 2003). A variation of this two-subdomain binding model, 'the collagen hug', has been proposed for the collagen-binding MSCRAMMs (Liu et al., 2007; Zong et al., 2005).

Previous in silico analyses have identified a family of genes that encode MSCRAMM-like proteins in the genomes of several Gram-positive bacteria, including our reports of the ebp (endocarditis and biofilm-associated pilus of Enterococcus faecalis) operon, Ace (adhesin of collagen from E. faecalis) and Acm (adhesin of collagen from $E$. faecium) (Bowden et al., 2005; Nallapareddy et al., 2000, 2003, 2006; Roche et al., 2003; Sillanpää et al., 2004; Xu et al., 2004). Recently, Hendrickx et al. (2007) predicted 22 CWA proteins from the E. faecium TX0016 [formerly DO (Arduino et al., 1994)] genome, of which five were found to be enriched in isolates of the hospital-adapted clonal complex 17 (CC17). However, with the exception of the prototype MSCRAMM Acm (Nallapareddy et al., 2003), there has been no demonstration of other MSCRAMMs in E. faecium. Although our previous report identified an essential and secreted broad-spectrum adhesin, SagA, that exhibits binding to fibrinogen, collagen type I (CI), collagen type IV (CIV), fibronectin and laminin, this protein lacks a CWA domain and other MSCRAMM characteristics (Teng et al., 2003).

In the present study, we identified 14 genes (in addition to $\mathrm{acm}$ ) that encode predicted MSCRAMMs in the genome of E. faecium TX0016. Recombinant forms of one of these proteins, designated $\mathrm{Scm}$ (for second collagen adhesin of $E$. faecium), were characterized to confirm the structural predictions and to identify its ligand. Cell-surface expression of $\mathrm{Scm}$ by selected E. faecium strains was quantified using FACS, and antibodies raised against a recombinant form of one of the major pilus proteins showed a highmolecular mass (HMM) ladder pattern characteristic of Gram-positive pili. Co-transcription of one of the pilusencoding gene clusters was demonstrated by Northern 
hybridization and RT-PCR. In addition, we determined the distribution of the MSCRAMM-encoding genes among 30 diverse E. faecium clinical isolates.

\section{METHODS}

Strains, plasmids and cultivation of bacteria. Relevant characteristics of bacterial strains, growth conditions and plasmids used in this study are summarized in Table 1 and in the Supplementary Methods. All constructs were given TX numbers and plasmids from these constructs were assigned corresponding pTEX numbers (Table 1).

Escherichia coli and E. faecium cells were grown in Luria-Bertani (LB) broth/agar and Brain Heart Infusion (BHI) broth/agar (Difco), respectively. For Escherichia coli constructs, antibiotics were used at the following concentrations: $25 \mu \mathrm{g}$ kanamycin $\mathrm{ml}^{-1}$ and $100 \mu \mathrm{g}$ ampicillin $\mathrm{ml}^{-1}$.

Identification and structural analysis of CWA proteins. Bioinformatics methods used for genome-wide identification of CWA proteins are described in the Supplementary Methods. Domain architecture as well as fold-recognition analyses were carried out by comparing the protein sequences against domain databases, as described in Supplementary Methods.

Construction of expression plasmids. Genomic DNA from E. faecium strains was isolated as described earlier (Wilson, 1994). DNA regions encoding amino acids 27-624 (A-domain and B-repeats) and 27-333 (A-domain) of $\mathrm{Scm}$, and amino acids 33-590 of $\mathrm{EbpC}_{\mathrm{fm}}$ [Fms9 was renamed $\mathrm{EbpC}_{\mathrm{fm}}$ based on its $74 \%$ amino acid identity (84\% similarity) with $\mathrm{EbpC}$ of E. faecalis over the entire protein (mature protein without the signal peptide and the CWA domain)], were amplified using primers listed in Supplementary Table S1 and cloned into the expression vector pQE30 (Qiagen) to obtain pTEX5432, pTEX5628 and pTEX5630 (Table 1). The corresponding expressed protein segments of $\mathrm{Scm}$ were designated $\mathrm{rScm}_{65}$ and $\mathrm{rScm}_{36}$, based on their calculated molecular masses. Similarly, the cloned segment of $\mathrm{EbpC}_{\mathrm{fm}}$ was designated $\mathrm{rEbpC}_{\mathrm{fm} 62}$. Constructs were confirmed by sequencing.

Purification of recombinant proteins. Recombinant proteins with $\mathrm{N}$-terminal $\mathrm{His}_{6}$-tags were expressed and purified using nickel affinity chromatography followed by anion-exchange chromatography (Nallapareddy et al., 2007; Sillanpää et al., 2004). Protein concentrations were determined by absorption spectroscopy at $280 \mathrm{~nm}$ using calculated molar absorption coefficient values. Molecular masses were determined with MALDI-TOF MS for $\mathrm{rScm}_{36}$ and $\mathrm{rScm}_{65}$.

Circular dichroism (CD) spectra. Far-UV CD spectroscopy data were collected as described previously (Sillanpää et al., 2004). Secondary structure compositions were quantified with ContinLL, SELCON3 and CDSSTR (http://www.cryst.bbk.ac.uk/cdweb/html/ home.html) (Lobley et al., 2002; Whitmore \& Wallace, 2004).

ELISA-type solid-phase ligand-binding assays. Binding of the recombinant His-tag fusion proteins to components of the extracellular matrix (ECM) was tested using an assay described previously, with minor modifications (Nallapareddy et al., 2000). In brief, $1 \mu \mathrm{g}$ of each ECM protein (for sources, see Supplementary Methods) was coated in $100 \mu \mathrm{l}$ PBS $(137 \mathrm{mM} \mathrm{NaCl}, 2.7 \mathrm{mM} \mathrm{KCl}, 4.3 \mathrm{mM}$ $\mathrm{Na}_{2} \mathrm{HPO}_{4}, 1.4 \mathrm{mM} \mathrm{KH} \mathrm{PO}_{4}, \mathrm{pH} 7.4$ ) in Immulon $2 \mathrm{HB}$ (Thermo Scientific) 96-well microplate wells. Wells were incubated with various concentrations of $\mathrm{rScm}$, and bound His-tag proteins were detected with anti-His ${ }_{6} \mathrm{mAb}$ (GE Healthcare) followed by alkalinephosphatase-conjugated anti-mouse antibody (Bio-Rad). p-nitrophenyl phosphate (Sigma) was used for signal detection.
Production of polyclonal antibodies and purification of antigen-specific Igs. Polyclonal goat antibodies against $\mathrm{rScm}_{36}$ and $\mathrm{rEbpC}_{\mathrm{fm} 62}$ were raised at Bethyl Laboratories. $\mathrm{Scm}_{36^{-}}$and $\mathrm{EbpC}_{\mathrm{fm} 62}$-specific Igs were eluted from CNBr-activated Sepharose $4 \mathrm{~B}$ coupled with the corresponding antigen, according to the manufacturer's protocol (GE Healthcare). Glycine $(0.1 \mathrm{M}, \mathrm{pH} 2.8)$ was used for elution of bound antibodies, which were neutralized immediately by $1 \mathrm{M}$ Tris/ $\mathrm{HCl}, \mathrm{pH} 8.0$, and dialysed extensively against PBS. Antibody concentrations were determined using an estimated IgG molar absorption coefficient value of $210000 \mathrm{M}^{-1} \mathrm{~cm}^{-1}$ and a molecular mass of 150000 Da.

Whole-cell ELISA and FACS. Surface expression of $\mathrm{Scm}$ on $E$. faecium cells was detected by a whole-cell ELISA assay (Nallapareddy et al., 2003) using affinity-purified $\mathrm{rScm}_{36}$-specific Igs. Antiserum against formalin-killed TX0016 whole cells (Rakita et al., 2000) was used as a positive control.

To quantify surface expression of Scm by FACS analysis, bacteria grown in $\mathrm{BHI}$ for $14 \mathrm{~h}$ from an inoculum of $\mathrm{OD}_{600}=0.01$ were labelled with preimmune or affinity-purified anti-Scm-specific antibodies followed by donkey anti-goat IgG conjugated with $\mathrm{F}\left(\mathrm{ab}^{\prime}\right)_{2}$-fragment-specific $R$-phycoerythrin, as described previously (Kemp et al., 2007). Cells were then fixed in $1 \%$ paraformaldehyde in PBS and analysed with a Coulter EPICSXL AB6064 flow cytometer (Beckman Coulter) and System II software.

Extraction of CWA proteins and Western blot analysis. CWA proteins were extracted from E. faecium strains grown for $8 \mathrm{~h}$ in $\mathrm{BHI}$ broth to late-exponential phase (starting inoculum, $\mathrm{OD}_{600} \sim 0.01$ ) with mutanolysin as described previously (Nallapareddy et al., 2006). Equal amounts of concentrated mutanolysin extracts were separated using $4-15 \%$ gradient SDS-PAGE gels (Bio-Rad) under reducing conditions, and transferred to PVDF membranes according to the manufacturer's protocol. Membranes were probed with affinitypurified anti-Scm $\mathrm{Sc}_{36}$ and anti-EbpC $\mathrm{Cm}_{\mathrm{fm} 2}$ antibodies (see above) followed by HRP-conjugated anti-goat IgG antibodies, and as a control, total IgG antibodies purified from preimmune goat sera were used. Signal was detected using SuperSignal West Pico chemiluminescent detection reagents (Thermo Scientific).

Northern hybridization. Using the RNAprotect bacteria reagent and RNeasy Mini kit (Qiagen), total RNA was isolated from TX0082 grown in BHI to mid-exponential phase. Samples $(30 \mu \mathrm{g})$ of total RNA were separated using a formaldehyde-containing agarose gel under denaturing conditions and transferred to a Hybond-N+ membrane, as described by the manufacturer (GE Healthcare). DNA probes obtained with primers listed in Supplementary Table S1 were radiolabelled by using the RadPrime DNA labelling system (Invitrogen). Hybridization was performed under high-stringency conditions, as detailed previously for Southern blots (Murray et al., 1993).

RT-PCR. Total RNA (isolated as above for Northern hybridization) was treated twice with $20 \mathrm{U}$ RQ1 DNase (Promega) for $30 \mathrm{~min}$ at $37^{\circ} \mathrm{C}$. DNase was removed using the RNeasy Mini kit and purification protocol (Qiagen). Total RNA was then reversetranscribed with specific primers (Supplementary Table S1) using the SuperScript One-Step RT-PCR with Platinum Taq kit (Invitrogen) according to the manufacturer's instructions. DNA sequencing verified that the primer regions of TX0082 were $100 \%$ identical to the corresponding sequences in TX0016. As an internal control, a 509 bp fragment of gyrA (encoding gyrase A) was amplified using the FmGyrF and FmGyrR primers (Supplementary Table S1). Reactions without reverse transcriptase were used as controls to verify lack of DNA contamination in the total RNA preparations. 
Table 1. Bacterial strains and plasmids used in this study

\begin{tabular}{|c|c|c|}
\hline Strain or plasmid & Relevant characteristics ${ }^{*}$; origin; year of isolation & Reference or source \\
\hline \multicolumn{3}{|l|}{ E. faecium strains } \\
\hline TX0016 (DO) & $\begin{array}{l}\text { Endocarditis isolate, } \operatorname{Van}^{\mathrm{S}}, \mathrm{Amp}^{\mathrm{R}} \text {; Houston, TX; } 1992 \\
\text { (http://www.hgsc.bcm.tmc.edu/projects/microbial/microbial-detail.xsp?project_id=118) }\end{array}$ & Arduino et al. (1994) \\
\hline TX2535 & Endocarditis isolate, $\operatorname{Van}^{\mathrm{R}}, \mathrm{Amp}^{\mathrm{R}}$; Houston, $\mathrm{TX} ; 1995$ & Nallapareddy et al. (2003) \\
\hline TX0068 & Endocarditis isolate, $\operatorname{Van}^{\mathrm{R}}, \mathrm{Amp}^{\mathrm{R}}$; Worcester, MA; 1994 & This study \\
\hline TX0074 & Endocarditis isolate, $\operatorname{Van}^{\mathrm{R}}, \mathrm{Amp}^{\mathrm{R}}$; Valhalla, NY; 1995 & This study \\
\hline \multicolumn{3}{|c|}{ Escherichia coli strains } \\
\hline M15(pREP4) & Escherichia coli strain for expression of recombinant proteins & Qiagen \\
\hline TX5432 & M15 (pTEX5432), Amp ${ }^{\mathrm{R}}, \operatorname{Kan}^{\mathrm{R}}$ & This study \\
\hline TX5628 & M15 (pTEX5628), Amp ${ }^{\mathrm{R}}, \mathrm{Kan}^{\mathrm{R}}$ & This study \\
\hline \multicolumn{3}{|l|}{ Plasmids } \\
\hline pQE30 & Expression vector & Qiagen \\
\hline pTEX5432 & $\begin{array}{l}1794 \text { bp fragment from TX0016 scm (encoding complete A- and B-domains) cloned into } \\
\text { pQE30 expression vector }\end{array}$ & This study \\
\hline pTEX5628 & $\begin{array}{l}921 \text { bp fragment from TX2535 scm (encoding complete A-domain) cloned into pQE30 } \\
\text { expression vector } \dagger\end{array}$ & This study \\
\hline pTEX5630 & $\begin{array}{l}1674 \mathrm{bp} \text { fragment from } \mathrm{TX} 0016 e b p C_{f m} \text { (encoding mature } \mathrm{EbpC}_{\mathrm{fm}} \text { without signal peptide } \\
\text { or CWA domain) cloned into pQE30 expression vector }\end{array}$ & This study \\
\hline
\end{tabular}

${ }^{\star} A m p^{\mathrm{R}}$, ampicillin resistant; $\mathrm{Kan}^{\mathrm{R}}$, kanamycin resistant; $\operatorname{Van}^{\mathrm{R}}$, vancomycin resistant.

$\dagger$ The DNA sequence of $s c m$ cloned into pTEX5628 from strain TX2535 is $100 \%$ identical with that of TX0016.

Colony hybridization. Preparation of colony lysate membranes and hybridization under high-stringency conditions were performed as described previously (Coque et al., 1995; Singh et al., 1998). DNA probes were generated and radiolabelled as described above for Northern hybridization.

\section{RESULTS AND DISCUSSION}

\section{Identification of putative CWA proteins with Ig- like folds}

Our search of the nearly completed genome sequence of $E$. faecium endocarditis-derived strain TX0016 (G. M. Weinstock \& B. E. Murray, unpublished data; http://www.hgsc.bcm. tmc.edu/) yielded a total of 22 ORFs encoding putative CWA proteins (designated Fms, for E. faecium surface proteins) with a tripartite pattern near the $\mathrm{C}$ terminus (an LPXTG motif or variant, followed by a membrane-spanning hydrophobic region and a positively charged tail). This number is in the range of predicted CWA proteins of related Gram-positive bacteria (Ponnuraj et al., 2003), which vary from eight (Streptococcus mutans) to 41 (E. faecalis). While the number of CWA proteins identified here is the same as the number reported in a recent study (Hendrickx et al., 2007) which identified CWA proteins from a partial TX0016 genome sequence (available at NCBI; accession no. NZ_AAAK00000000), the published report did not include one of the ORFs reported here (Fms6) and classified a pseudogene (Fms15) as two ORFs (Supplementary Results).

Among these 22 putative CWA proteins, 18 contained a predicted $\mathrm{N}$-terminal signal peptide sequence required for
Sec-dependent secretion. Further analysis of the 5 ' regions of the remaining four ORFs (Fms14, Fms15, Fms16 and Fms19) that lack a signal peptide revealed the presence of $\mathrm{N}$-terminal signal peptides in the ORFs immediately upstream of Fms15, Fms16 and Fms19. Careful examination of the junction regions showed the presence of a premature stop codon due to a point mutation or frameshift in fms15, fms16 and fms 19 (Supplementary Results). Sequencing of fms 16 and fms 19 regions from additional isolates identified intact fms 16 and fms 19 genes in two of 10 E. faecium clinical isolates tested (Supplementary Results). However, we did not find an E. faecium strain with an intact fms15 gene (Supplementary Results).

Subsequently, using the fold recognition servers 3D-PSSM and PHYRE, we identified 15 of the predicted Fms proteins (Table 2) as containing one or more Ig-like folds enriched with $\beta$-sheets, and only a small quantity of $\alpha$-helices; similar secondary structure compositions have been found in the ligand-binding A-regions of MSCRAMMs (Deivanayagam et al., 2002). One of these, Fms8, had been previously identified in our laboratory as Acm (Nallapareddy et al., 2003). The percentage of E. faecium LPXTG proteins containing Ig-like folds is greater than the percentages for other Gram-positive bacteria (22-45\%) (Ponnuraj et al., 2003). The Ig-like fold-containing modules of the A-domain of a number of well-characterized Staphylococcus aureus MSCRAMMs (e.g. the fibronectin-, fibrinogen- and elastin-binding protein FnbpA, the fibrinogen-binding proteins ClfA and ClfB, and the collagen-binding protein $\mathrm{Cna}$ ) and the prototype MSCRAMM of E. faecium, Acm, have been shown to play 
a direct role in interactions with their respective ECM protein ligands (Nallapareddy et al., 2007; Ponnuraj et al., 2003; Zong et al., 2005).

\section{Structural organization of the E. faecium putative MSCRAMMs}

Because of our interest in surface adhesins, we next performed additional analyses on the subset of predicted Ig-like fold-containing proteins and found that most were predicted to have a multi-domain architecture similar to the characterized MSCRAMMs of S. aureus and E. faecalis (Deivanayagam et al., 2002; Perkins et al., 2001; Sillanpää et al., 2004) (Supplementary Results). A schematic of the predicted primary sequence organization of these proteins is depicted in Fig. 1. The N-terminal signal peptide sequences, found in all but Fms14, were 24-56 aa in length. The majority had perfectly conserved canonical LPXTG motifs, while six had anchor motifs with a broader consensus (Table 2).

\section{Individually organized genes encoding putative MSCRAMMs}

Fms10, Fms15 and Fms18, like Acm, are encoded by individual genes and are not clustered with other MSCRAMM-encoding genes. Among these, Fms18 has $94 \%$ similarity (Table 2) to the E. faecalis MSCRAMM EF1896, which is predicted to be mostly Ig-folded and shows binding to a serum protein (J. Sillanpää, S. R. Nallapareddy, B.E. Murray and M. Hook, unpublished data). Scm (Fms10) of TX0016 has 13 B-repeats of 19 aa in length and a partial repeat of $10 \mathrm{aa}$, while pseudogene fms 15 is predicted to encode eight B-repeats of 91-93 aa in length. The primary sequences of $\mathrm{Scm}$ and Fms15 each predict a single subdomain with an Ig-like fold in the Adomain, unlike the well-established MSCRAMMs, which have two to three subdomains. Hence, we hypothesize that if these proteins are adhesins, they may adopt a different binding mechanism, and we chose $\mathrm{Scm}$ for further characterization.

\section{Characteristics of recombinant Scm protein segments}

Total yields of the recombinant protein $\mathrm{rScm}_{65}$ (fully mature protein consisting of the A-domain and B-repeats; amino acids 27-624) were low. Although we estimated that this protein was over $95 \%$ pure immediately after eluting from the chromatographic columns, as shown in Supplementary Fig. S1, it was susceptible to partial degradation even after brief storage. $\mathrm{rScm}_{65}$ migrated as a larger band than expected from the calculated molecular mass of $64.5 \mathrm{kDa}$, likely due to the highly acidic nature (pI 3.9) of the protein. To obtain a stable construct with higher yields, we next expressed $\mathrm{rScm}_{36}$ encompassing the complete A-domain (amino acids 27-333; Supplementary Fig. S1). A MALDI-TOF MS analysis determined the molecular mass of $\mathrm{rScm}_{36}$ to be $35711 \mathrm{Da}$, which is in good agreement with the calculated mass of $35691 \mathrm{Da}$, and confirmed the absence of post-translational modifications and the homogeneity of the purified protein. As an additional confirmation of the identities of the purified protein segments and evidence of their intact $\mathrm{N}$ termini, a monoclonal anti-His $s_{6}$ antibody detected the $\mathrm{N}$-terminal $\mathrm{His}_{6}$ fusion in both purified protein segments in a Western blot assay (data not shown).

\section{Recombinant Scm binds to collagen in a dose- dependent manner}

Since the adhesive functions of previously studied MSCRAMM proteins have mostly been ascribed to binding to protein components of the host ECM, we examined the potential ECM-adhesive functions of $\mathrm{Scm}$ by testing its binding to a panel of individual ECM proteins in an ELISA-type solid-phase ligand-binding assay. As seen in Fig. 2(a), both $\mathrm{rScm}_{65}$ (containing the full mature protein) and $\mathrm{Scm}_{36}$ (containing only the A-domain) exhibited significant binding to CV (35-fold and 82-fold, respectively, higher than the background level seen with immobilized BSA). Interestingly, stronger binding of these $\mathrm{rScm}$ proteins (especially $\mathrm{rScm}_{36}$ ) to fibrinogen and $\mathrm{CI}$ was also observed compared with their binding to CIV, laminin, and fibronectin (Fig. 2a).

Further analysis of the binding interactions of increasing concentrations of $\mathrm{rScm}_{36}$ with $\mathrm{CI}$ and $\mathrm{CV}$, as well as fibrinogen, by dose-response assays showed concentrationdependent binding of $\mathrm{rScm}_{36}$ to $\mathrm{CV}$ that approached saturation, with apparent half-maximal binding $\left(K_{\mathrm{D}}\right)$ reached at $30.8 \pm 1.8 \mu \mathrm{M}$ (Fig. $2 \mathrm{~b}$ ). The apparent affinity of $\mathrm{rScm}_{36}$ for fibrinogen and $\mathrm{CI}$ was low and did not reach reliable saturation levels. In spite of partial degradation, $\mathrm{Scm}_{65}$ showed dose-dependent binding, with an affinity for $\mathrm{CV}$ similar to that for $\mathrm{Scm}_{36}$ (data not shown). Although $K_{\mathrm{D}}$ values from steady-state assays are estimates, our affinity determination for the Scm A-domain is in the same range as that shown previously for the minimal ligandbinding domain of Ace to CI $(48 \pm 7 \mu \mathrm{M})$ (Rich et al., 1999), but lower than that for the A-domain of Acm to CI $(3.8 \mu \mathrm{M})$ or CIV $(12.8 \mu \mathrm{M})$ (Nallapareddy et al., 2003). Interestingly, Acm did not show appreciable binding to $\mathrm{CV}$ (data not shown) and bound efficiently to CI, and to a lesser degree to CIV, in agreement with our previous report (Nallapareddy et al., 2003). Taken together, our results suggest that $\mathrm{CV}$ is a binding ligand for $\mathrm{Scm}$ and that this binding is mediated by the A-domain.

The three collagen types included in our assays have distinct structures and tissue distributions. $\mathrm{CI}$ is the most abundant form and the main component of the collagen fibres that are widely distributed in human tissues, while CIV forms structurally different cross-linked networks and is found nearly exclusively in basement membranes. CV, although quantitatively less abundant, has a critical role in formation of the fibrillar collagen matrix and connecting interstitial 
Table 2. Summary of features of the predicted MSCRAMM proteins of E. faecium and the distribution of the corresponding genes in $30 \mathrm{E}$. faecium isolates associated with clinical infections

\begin{tabular}{|c|c|c|c|c|c|}
\hline Gene name & $\begin{array}{l}\text { Accession } \\
\text { number }\end{array}$ & $\begin{array}{l}\text { Protein length } \\
\text { (aa) }\end{array}$ & $\begin{array}{l}\text { Cell wall } \\
\text { anchoring motif }\end{array}$ & $\begin{array}{l}\text { Best match to other CWA proteins } \\
\text { (similarity, \%) }\end{array}$ & $\begin{array}{l}\text { Number of isolates } \\
\text { positive }(\%)(n=30)\end{array}$ \\
\hline \multicolumn{6}{|c|}{ Genes not clustered } \\
\hline $\mathrm{acm}^{\star}(\mathrm{fms} 8)$ & ZP_00604683 & 721 & LPKTS & Staph. aureus Cna $(62 \%)^{*}$ & $30(100 \%)$ \\
\hline$s c m(f m s 10)$ & ZP_00604835 & 660 & LPKTG & Lactobacillus brevis hypothetical protein (54\%) & $30(100 \%)$ \\
\hline$f m s 15 \dagger$ & ZP_00602631 & 1412 & LPKTG & $\begin{array}{l}\text { Bacillus anthracis collagen-binding protein BA0871 } \\
(49 \%)\end{array}$ & $29(97 \%)$ \\
\hline fms18 & ZP_00603098 & 1075 & FPQTG & E. faecalis EF1896 (91\%) & $24(80 \%)$ \\
\hline \multicolumn{6}{|l|}{ Cluster 1} \\
\hline$e b p A_{f m}(f m s 1)$ & ZP_00602689 & 1129 & LPETG & E. faecalis EbpA (75\%) & $29(97 \%)$ \\
\hline$e b p B_{f m}(f m s 5)$ & ZP_00602688 & 473 & LPKTN & E. faecalis $\mathrm{EbpB}(65 \%)$ & $29(97 \%)$ \\
\hline$e b p C_{f m}(f m s 9)$ & ZP_00602687 & 625 & LPSTG & E. faecalis $\mathrm{EbpC}(84 \%)$ & $29(97 \%)$ \\
\hline \multicolumn{6}{|l|}{ Cluster 2} \\
\hline fms11 & ZP_00604460 & 773 & LPSTG & Lactobacillus johnsonii hypothetical protein (46\%) & $29(97 \%)$ \\
\hline fms $19 \ddagger$ & ZP_00604462 & 499 & FPKTS & E. faecalis $\operatorname{EbpB}(54 \%)$ & $29(97 \%)$ \\
\hline$f m s 16 \ddagger$ & ZP_00604464 & 470 & LPSTG & E. faecalis EbpC (46\%) & $29(97 \%)$ \\
\hline \multicolumn{6}{|l|}{ Cluster 3} \\
\hline$f m s 14 \S$ & ZP_00603043 & 1313 & LPATG & E. faecalis EbpA (41\%) & $30(100 \%)$ \\
\hline fms17 & ZP_00603042 & 437 & FPQTN & E. faecalis EbpB (47\%) & $30(100 \%)$ \\
\hline$f m s 13$ & ZP_00603041 & 565 & LPATG & E. faecalis $\mathrm{EbpC}(25 \%)$ & $30(100 \%)$ \\
\hline \multicolumn{6}{|l|}{ Cluster 4} \\
\hline$f m s 21$ & ZP_00603529 & 658 & VPMTG & E. faecalis $\mathrm{EbpC}(41 \%)$ & $28(93 \%)$ \\
\hline$f m s 20$ & ZP_00603526 & 696 & VPKTG & E. faecalis EF2525 (41\%) & $22(73 \%)$ \\
\hline
\end{tabular}

${ }^{\star}$ Identified in our previous studies (Nallapareddy et al., 2003).

$\dagger$ In silico analysis predicts a one-nucleotide deletion in the B-repeat region.

¥These genes had a nucleotide substitution or deletion in E. faecium strain TX0016 versus TX0068 and TX0074, resulting in pseudogenes.

$\S$ Fms14 lacks an identifiable signal peptide, but has the other characteristics of a CWA protein.

collagen fibrils with membranous collagen networks (Nicholls et al., 1996; Wenstrup et al., 2004). Considering the diverse tissue localizations and structural differences of the various collagen types, the possession of two collagen adhesins with different binding specificities to various collagen types could give E. faecium the ability to fine-tune its adherence phenotype to suit a given tissue. Since collagens, including $\mathrm{CV}$, are also present in the intestinal submucosa (Liang et al., 2006), Scm could alternatively be involved in colonization and persistence in the intestinal tract, a major natural reservoir of both commensal and infection-associated strains of E. faecium in humans, or in facilitating translocation through damaged intestinal epithelium.

\section{Structural analysis of recombinant $\mathrm{Scm}$ protein}

To investigate the structural predictions made above, we analysed the full A-domain of $\mathrm{Scm}$ with far-UV CD spectroscopy. The spectra obtained showed a maximum at $197 \mathrm{~nm}$, another at $191 \mathrm{~nm}$, and a minimum at $217 \mathrm{~nm}$ (Fig. 3a). A similar overall pattern was observed with the collagen-binding A-domain of the E. faecium prototype MSCRAMM Acm, which we have characterized previously (Nallapareddy et al., 2003, 2007), and also with the minimal collagen-binding region of Ace from E. faecalis, which crystal structure studies have recently revealed folds into a similar $\mathrm{DEv}$ variant of the Ig-fold as that found previously in the ligand-binding A-domains of staphylococcal MSCRAMMs (Liu et al., 2007). Deconvolution of the collected data showed a secondary structure composition of $0.15 \pm 0.03 \alpha$-helix and $0.34 \pm 0.01 \beta$-sheet for $\mathrm{rScm}_{36}$ (Fig. 3b). Although the helical content of this protein is slightly higher than in the two control proteins, these results generally resemble the overall secondary structure compositions of the ligand-binding regions of Acm and Ace, and are in good agreement with earlier CD analyses and crystal structure data of other MSCRAMM A-regions (Rich et al., 1999). While fold analyses and multiple alignments predicted a single Ig-folded subunit from amino acids $125-325$ in the A-domain of $\mathrm{Scm}$, our CD measurements indicate a high $\beta$-sheet composition for the entire $\mathrm{Scm}$ A-domain, thus suggesting that an Igfolded or similar $\beta$-sheet-rich structure may extend over the whole A-domain (amino acids 27-333).

\section{Cell surface expression of $\mathrm{Scm}$}

Using Scm-specific antibodies affinity-purified (with $\mathrm{rScm}_{36}$ ) from goat antiserum, we assessed the surface expression of $\mathrm{Scm}$ by eight E. faecium clinical isolates (including the sequenced strain TX0016) using whole-cell 
(a)

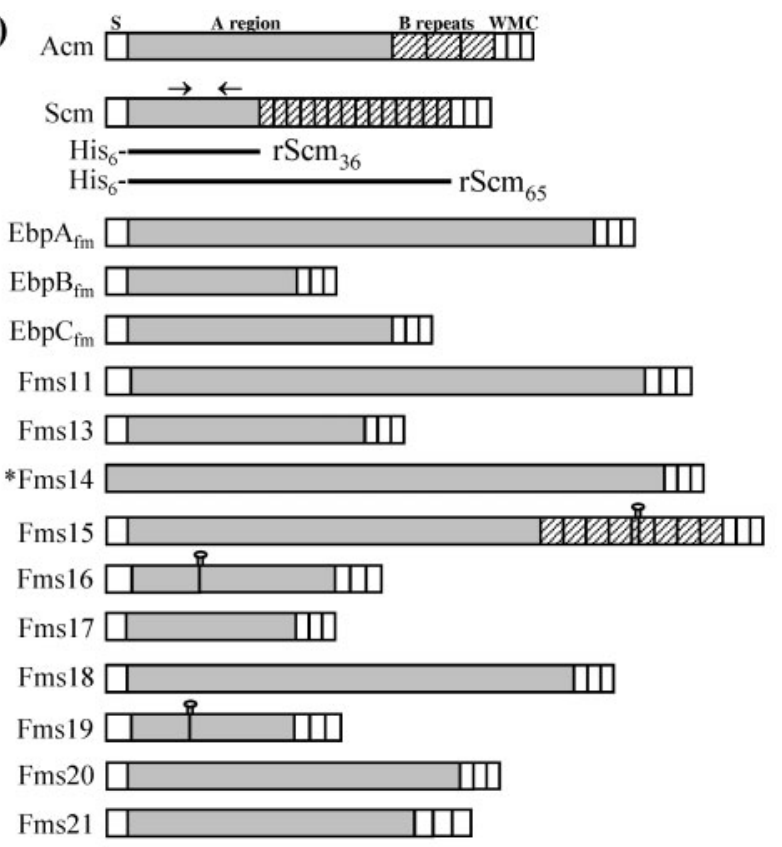

(b)

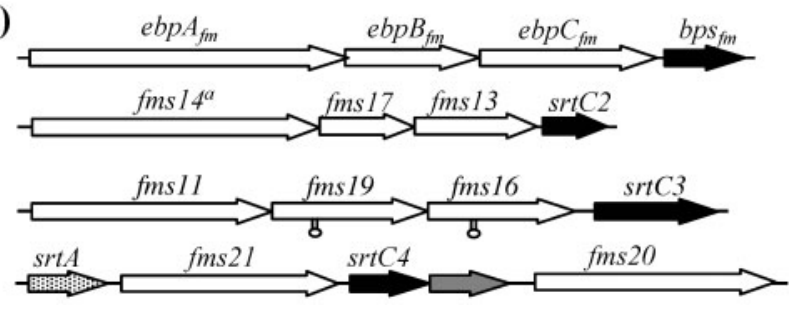

Fig. 1. Domain organization of $E$. faecium CWA proteins with Iglike folds. (a) S, signal peptide; W, cell wall anchor region; $M$, membrane-spanning region; $\mathrm{C}$, cytoplasmic tail with charged residues; shaded $A$ region, non-repetitive sequences; hatched $B$ region, repetitive sequences; lollypops denote the presence of a stop codon due to a nucleotide substitution/deletion in Fms15, Fms16 and Fms19 of TX0016; solid black bars, $\mathrm{His}_{6}$-tagexpressed regions of $\mathrm{Scm}$ (Fms10). Arrows above $\mathrm{Scm}$ show regions with predicted Ig-like folding. (b) Contiguously arranged ORFs encoding CWA proteins in the E. faecium genome; srt, gene encoding sortase. ${ }^{*} \mathrm{Fms} 14$ lacks an identifiable signal peptide, but has all the other characteristics of CWA MSCRAMMs.

ELISA. Two E. faecium community-derived strains that lacked $\mathrm{scm}$ (identified below) were used as negative controls. Among eight $\mathrm{scm}^{+}$isolates, four (TX0074, TX2535, TX2400 and TX2589) were strongly positive, two (TX0068 and TX2081) were positive, one (TX2416) was weakly positive and one (TX0016) was negative in this assay (see Supplementary Fig. S2), suggesting that $\mathrm{Scm}$ is produced on the cell surface of many E. faecium isolates during in vitro growth. Subsequent quantification of $\mathrm{Scm}$ surface expression in these isolates by FACS (Fig. 4) showed variable levels of surface expression, with the percentage of cells expressing $\mathrm{Scm}$ ranging from 2.3 to $96.9 \%$. In strains TX0074, TX2535, TX2400 and TX2589,
Scm was detected on the surface of $90-97 \%$ of cells and with relatively high fluorescence intensities, thus confirming our observations with whole-cell ELISA. Furthermore, these surface detection studies suggested that the majority of cells of $\mathrm{scm}^{+}$isolates were actively producing $\mathrm{Scm}$ on the cell surface during in vitro growth. Consistent with our whole-cell ELISA and FACS results, a Western blot assay using the anti- $\mathrm{Scm}_{36}$ antibody identified a protein band corresponding to the expected size of mature $\mathrm{Scm}$ $(\sim 63 \mathrm{kDa})$ in mutanolysin cell wall extracts from TX0074 and TX2535, but not from TX0016 (data not shown).

\section{Eleven of 15 putative MSCRAMM-encoding genes are clustered at four different genomic loci, and nine are predicted to produce four distinct types of pili}

Unlike Acm, Scm (Fms10), Fms15 and Fms18, the remaining 11 putative MSCRAMM genes were found to be clustered in four genomic loci. Nine of the clustered genes showed significant similarity to pilus-associated proteins from other species (Table 2). Analysis of the nucleotide sequence of the locus spanning fms $1, f m s 5$ and $e b p C_{f m}(f m s 9)$ predicted the presence of four ORFs, all oriented in the same direction, including an $s r t C 1$ gene encoding a class $\mathrm{C}$ (subfamily 3 ) sortase (Fig. 1b). We subsequently renamed Fms1, Fms5 and SrtC1 as $\mathrm{EbpA}_{\mathrm{fm}}, \mathrm{EbpB}_{\mathrm{fm}}$ and $\mathrm{Bps}_{\mathrm{fm}}$, respectively, based on their high sequence identity with the E. faecalis Ebp cluster proteins (Nallapareddy et al., 2006) (Table 2). A similar arrangement of predicted pilus-associated proteins with an adjacent class $C$ sortase was found in the fms 14-17-13 and the fms11-19-16 clusters. Besides our prediction of ebpABC $f m$, fms14-17-13 and fms11-19-16 co-transcription, due to short or overlapping intergenic regions, we were unable to identify transcriptional terminator-like sequences in these gene clusters; thus, it is likely that these genes are in three operons (see also below). The genes encoding Fms 20 and Fms21 were found to be located close to each other in the genome, separated by two ORFs. One of these ORFs encodes a predicted class $\mathrm{C}$ sortase (SrtC4). In addition to $\mathrm{stC} C 4$, this locus also contains one class A sortase-encoding gene ( $\operatorname{srtA}$ ) immediately upstream of fms 21 (Fig. 1b). Another ORF located between SrtC4 and Fms20 shows $27 \%$ similarity to the EbpB pilus protein and has a signal peptide sequence but no CWA motif. Of note, the E. faecium TX0016 genome also contains a sixth sortase gene (srtC5) predicted to encode a class $\mathrm{C}$ sortase. However, none of the CWA protein genes was associated with the $\operatorname{srtC5}$ locus.

Subsequent in silico predictions identified conserved pilin motifs and E-boxes of Gram-positive pilus proteins in all four predicted major pilus protein homologues $\left(\mathrm{EbpC}_{\mathrm{fm}}\right.$, Fms13, Fms16 and Fms21) and all five of the predicted accessory protein homologues $\left(\mathrm{EbpA}_{\mathrm{fm}}, \mathrm{EbpB}_{\mathrm{fm}}, \mathrm{Fms} 14\right.$, Fms17 and Fms19) associated with the four gene clusters described above (Supplementary Fig. S3). The lysine (K) residue of the pilin motif and the glutamic acid (E) of the Ebox that have been demonstrated to be essential in the 
(a)

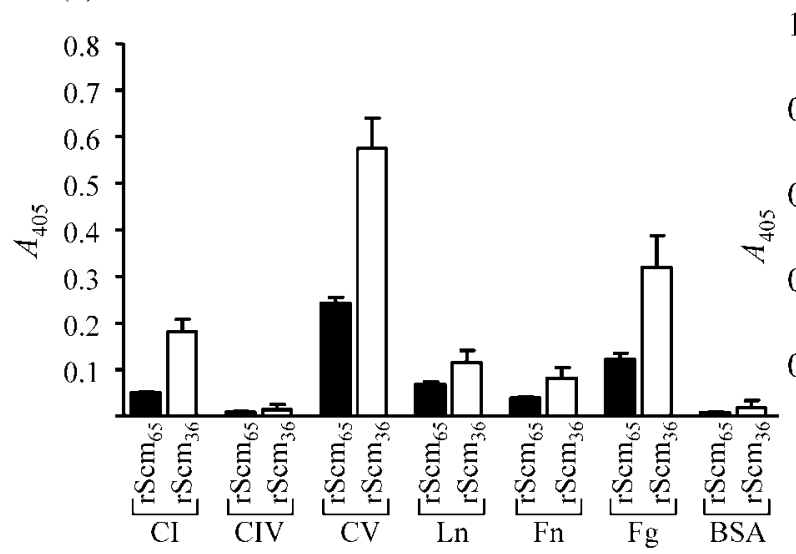

Extracellular matrix proteins (b)

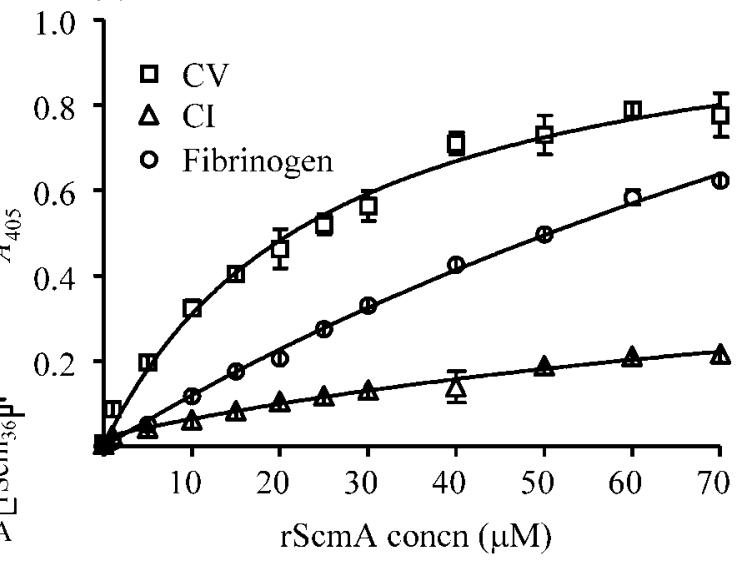

Fig. 2. Binding of recombinant Scm proteins to ECM proteins in a solid-phase ELISA-type ligand-binding assay. (a) Binding of $20 \mu \mathrm{M} \mathrm{rScm} 65$ (amino acids 27-624) and $\mathrm{rScm}_{36}$ (amino acids 27-333) to a collection of immobilized ECM proteins. Ln, laminin; Fn, fibronectin; Fg, fibrinogen. Data points for $\mathrm{rScm}_{36}$ represent the means of $A_{405}$ values of 18 wells representing six independent experiments and including proteins from two different purifications, and for $\mathrm{rScm}_{65}, 15$ wells from five independent assays. (b) Binding of $\mathrm{rScm}_{36}$ to $\mathrm{Cl}, \mathrm{CV}$ and fibrinogen with increasing $\mathrm{rScm}_{36}$ concentrations. Data points represent the means of $A_{405}$ values from three wells. The experiment was repeated up to six times using protein from two purifications. The reported $K_{\mathrm{D}}$ value is the mean $\pm \mathrm{SE}$ from the six assays. BSA-binding values were subtracted from the respective collagen-binding values, after which affinity calculations were performed with the one-ligand binding site model. The resulting curves are depicted.

polymerization of the Corynebacterium diphtheriae pilus (Ton-That \& Schneewind, 2003; Ton-That et al., 2004) were found to be $100 \%$ conserved. Two accessory proteins, namely $\mathrm{EbpA}_{\mathrm{fm}}$ and Fms14, have a von Willebrand factor type A-domain with a MIDAS motif which is frequently found in pili-associated accessory proteins. Recently, crystal structure analyses of the minor pilin protein GBS52 of Streptococcus agalactiae and the major pilin Spy0128 of Streptococcus pneumoniae have demonstrated that these proteins contain two Ig-like domains (Kang et al., 2007; (a)

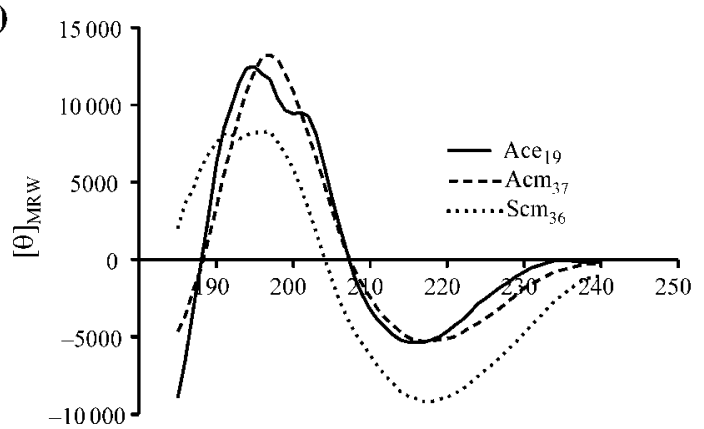

Wavelength (nm)

(b)

\begin{tabular}{lcccc} 
& \multicolumn{4}{c}{ Secondary structure composition } \\
\cline { 2 - 5 } & $\alpha$-Helix & $\beta$-Sheet & Turn & Unordered \\
\hline $\mathrm{Scm}_{36}$ & $0.15 \pm 0.03$ & $0.34 \pm 0.01$ & $0.22 \pm 0.02$ & $0.30 \pm 0.03$ \\
Ace $_{19}$ & $0.04 \pm 0.03$ & $0.47 \pm 0.02$ & $0.25 \pm 0.02$ & $0.27 \pm 0.03$ \\
$\mathrm{Acm}_{37}$ & $0.06 \pm 0.01$ & $0.43 \pm 0.02$ & $0.23 \pm 0.02$ & $0.28 \pm 0.01$ \\
\hline
\end{tabular}

Fig. 3. Secondary structure analysis by far-UV CD spectroscopy. (a) Collected CD spectra of $\mathrm{Scm}_{36}, \mathrm{Ace}_{19}$ and $\mathrm{Acm}_{37}$. Mean residue weight ellipticity is reported in degrees $\mathrm{cm}^{-2}$ $\mathrm{dmol}^{-1}$. (b) Summary of secondary structure compositions. ${ }^{*} \mathrm{~S}_{36}$ contains the predicted A-domain of Scm (amino acids 27-333). Ace $_{19}$ and $A_{c m}$ contain the corresponding minimal and high-affinity ligand-binding regions of the collagen-binding MSCRAMMs Ace (E. faecalis) and Acm (E. faecium), respectively. 

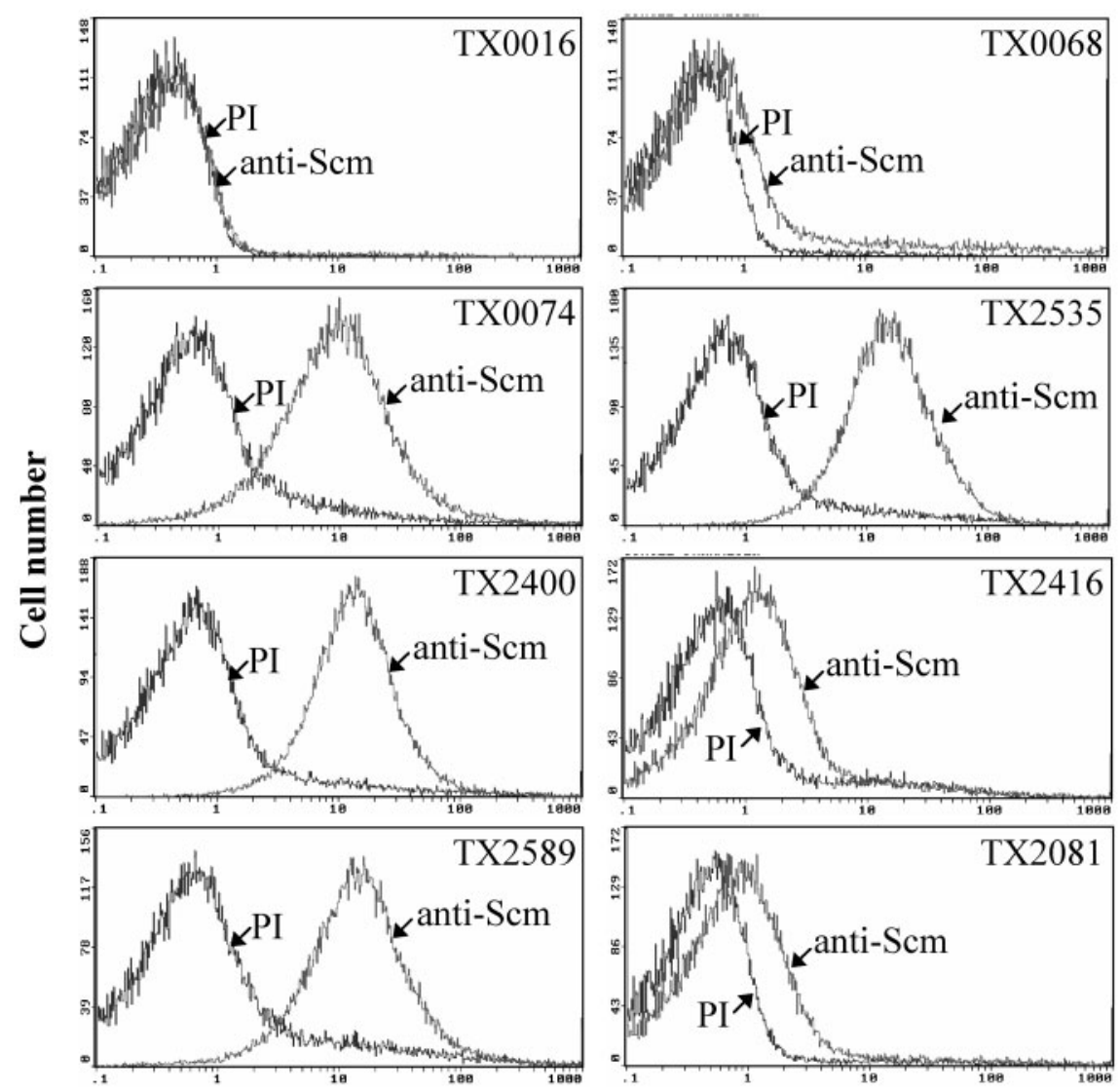

Fluorescence intensity

Fig. 4. Quantification of Scm surface expression by FACS analysis. Reactivity of both preimmune lgs (PI) and anti-Scm Igs for each strain is shown. Although some E. faecium isolates exhibited slight binding to goat PI, significant differences were observed between PI and anti-Scm Igs. Bacteria were analysed using side scatter as the threshold for detection. Specific binding by anti-Scm antibodies is indicated as fluorescence intensity on the $x$ axis using a log scale. Each histogram represents 50000 events of bacterium-sized particles.

Krishnan et al., 2007), consistent with our prediction of Iglike folds in E. faecium pilus proteins. These features, together with the presence of an independent class $\mathrm{C}$ sortase (class $\mathrm{C}$ sortases are used in the assembly of pili of related Gram-positive bacteria) in each of the four clusters, indicate that E. faecium may harbour genes for multiple pilus-like structures. Recent studies on the pili of $C$. diphtheriae, E. faecalis, group A and B streptococci, and pneumococci have demonstrated their role in bacterial adherence and biofilm formation, and their contribution to bacterial pathogenesis and modulation of the host immune system (Barocchi et al., 2006; Dramsi et al., 2006; Mandlik et al., 2007; Nallapareddy et al., 2006; Singh et al., 2007; Telford et al., 2006).

\section{$E_{b p C}$ is present as an HMM polymeric protein complex at the cell surface of $E$. faecium}

To confirm the predicted location of $\mathrm{EbpC}_{\mathrm{fm}}$ on the surface of E. faecium as part of polymeric pili, we probed mutanolysin cell wall extracts of endocarditis-derived E. faecium strains
TX0082 and TX0016 with affinity-purified anti-rEbpC $\mathrm{fm}_{\mathrm{fm}}$ antibodies. A ladder-like pattern of HMM bands with sizes greater than $200 \mathrm{kDa}$ was detected from strain TX0082 (Fig. 5). In contrast, only a single band has been observed with Acm in mutanolysin extracts of TX0082 (Nallapareddy et al., 2003). The HMM banding pattern is consistent with observations of a large number of pilus proteins from other Gram-positive bacteria and suggests that $\mathrm{EbpC}_{\mathrm{fm}}$ is assembled similarly into multimeric pilus structures on the E. faecium cell surface. In contrast to TX0082, no signal was detected from the cell wall extract of TX0016, which is similar to our whole-cell ELISA results (data not shown) and indicates that the $\mathrm{EbpC}_{\mathrm{fm}}$-containing pilus is not expressed in this strain under the growth conditions used.

\section{The ebpABC $C_{f m}$ genes are transcribed as a single polycistronic mRNA}

As stated above, bioinformatics analyses indicated that each of the four pilus-encoding gene clusters is likely to be 


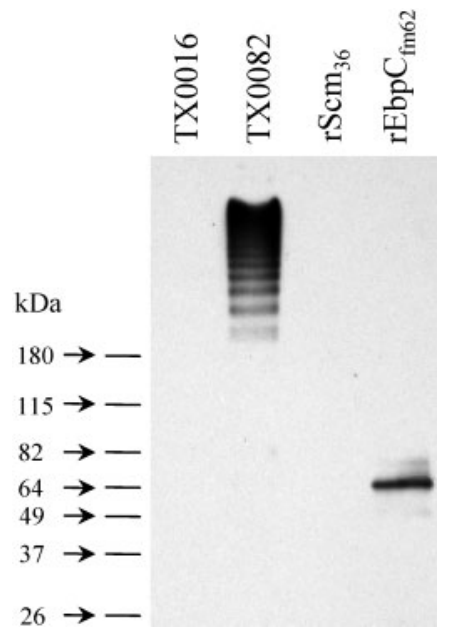

Fig. 5. Western blot analysis of cell wall anchored proteins from E. faecium strains TX0082 and TX0016. The mutanolysin cell wall extracts $(10 \mu \mathrm{g}$ total protein per lane) were separated on $4-15 \%$ SDS-PAGE gels, transferred to PVDF membranes, and probed using affinity-purified anti-rEbpC $\mathrm{f}_{\mathrm{fm} 62}$ antibodies. Purified $\mathrm{rScm}_{36}$ and $\mathrm{rEbpC}_{\mathrm{fm} 62}$ proteins (20 ng per lane) were included as controls.

organized as an operon. For the $e b p A_{f m}$ to $b p s_{f m}$ cluster, a $12 \mathrm{bp}$ inverted repeat that could form a stem-loop structure [free energy of $-22.55 \mathrm{kcal} \mathrm{mol}^{-1}(94.34 \mathrm{~kJ}$ $\mathrm{mol}^{-1}$ )] located in the intergenic region between $e f b C_{f m}$ and $b p s_{f m}$ is likely to function as a $\rho$-independent transcriptional terminator, thus predicting an $e f b A_{f m}$ to $e f b C_{f m}$ transcript and an independent $b p s_{f m}$ transcript. To validate this, we carried out transcriptional analyses of the $e b p A_{f m}$ to $b p s_{f m}$ locus using Northern hybridization. The $e b p A_{f m}, e b p B_{f m}$ and $e b p C_{f m}$ probes all hybridized to a single RNA band of $\sim 7 \mathrm{~kb}$ (Fig. 6a) which corresponds to the expected size of a polycistronic ebpABC $C_{f m}$ mRNA transcript, demonstrating that these three genes are cotranscribed. Probing with $b p s_{f m}$ detected a very low intensity band $(\sim 1 \mathrm{~kb})$, consistent with the expected size of a monocistronic $b p s_{f m}$ mRNA transcript, suggesting that this transcript either is produced at low levels at this time point or has a relatively short half-life. RT-PCR using three independent sets of internal $b p s_{f m}$ primer pairs amplified fragments of the expected sizes (lane 4 of Fig. 6b) (data not shown for two additional primer pairs), thus confirming the expression of $b p s_{f m}$. Another faint band of $\sim 8 \mathrm{~kb}$ was also observed with the $b p s_{f m}$-probed Northern blots; while its identity is currently unclear, it might represent a related mRNA sequence such as one transcribed from the other predicted pilus operons.

RT-PCR experiments on the ebpfm operon with primers designed to amplify intergenic regions of co-transcribed genes confirmed the expected amplification between $e b p A_{f m}$ and $e b p B_{f m}$ as well as $e b p B_{f m}$ and $e b p C_{f m}$, but not between $e b p C_{f m}$ and $b p s_{f m}$ (Fig. 6b). Taken together, our data demonstrate unambiguously that the E. faecium Ebp $_{\mathrm{fm}}$ pilus-encoding gene cluster represents a three-gene operon, unlike the E. faecalis locus, which produces a four-gene $e b p-b p s$ transcript in addition to an independent $b p s$ transcript (Nallapareddy et al., 2006).

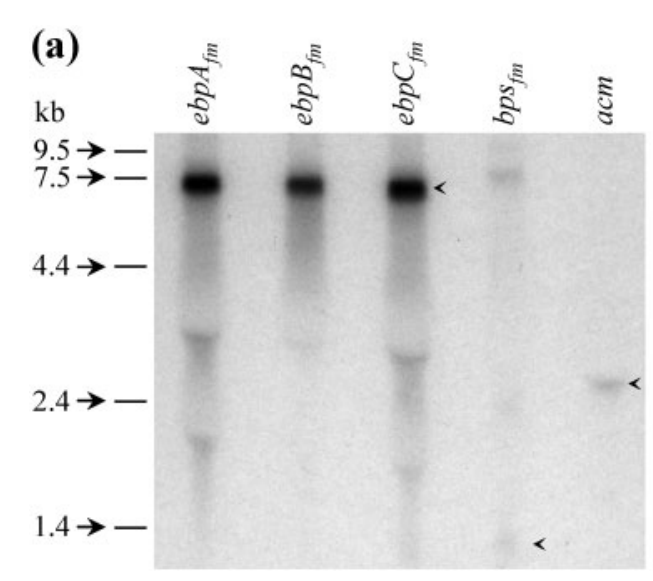

(b)

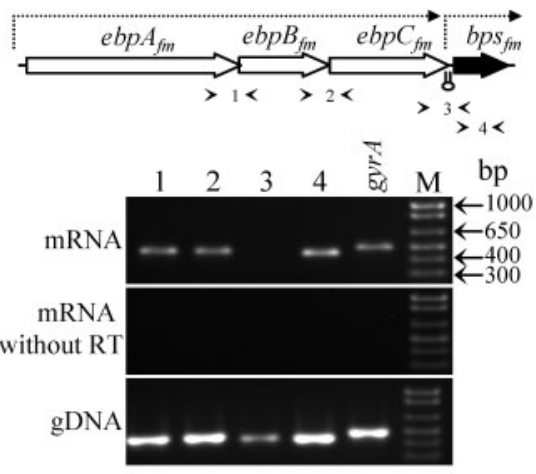

Fig. 6. Transcriptional analysis of the $e b p A_{f m}$ to $b p s_{f m}$ gene cluster. (a) Northern hybridization of total RNA ( $30 \mu \mathrm{g}$ per lane) from TX0082 probed with intragenic fragments of ebp $A_{f m}, e b p B_{f m}, e b p C_{f m}$ and $b p s_{f m}$. The acm probe was used as a control. RNA bands of the expected sizes are indicated with arrows. (b) RT-PCR analysis of the ebp $A_{f m}$ to $b p s_{f m}$ gene cluster. The location of each primer pair is indicated by arrows in the schematic representation of the gene cluster. A lollypop between $e b p C_{f m}$ and bps depicts a predicted transcriptional terminator. Top gel, RT-PCR with DNase-treated total RNA (10 ng) as template; middle gel, control reaction of the same total RNA (100 ng) preparation amplified without reverse transcriptase; bottom gel, control reaction amplified with genomic TX0082 DNA as template. An intragenic region of gyrase A was used as a control. M, molecular mass marker. 


\section{Genes encoding MSCRAMM and pili proteins are commonly found in $E$. faecium isolates of clinical origin}

We next examined 30 diverse (source/year/geographical location) human clinical isolates by colony hybridization using PCR-generated DNA probes. E. faecium strain TX0016 and the $\mathrm{acm}$ gene served as controls for the hybridization studies. As shown in Table 2, the percentage of isolates showing hybridization to the individual gene probes varied from $73 \%$ ( $f m s 20)$ to $100 \%$. The range in the number of probes hybridizing per isolate varied from 11 genes in one isolate (that lacked fms 15, fms $18, f m s 20$ and fms21) to all 15 genes in 16 isolates $(53 \%)$. One isolate lacked the $e b p A B C_{f m}$ (fms1-5-9) operon and another lacked the fms11-19-16 operon. The $s c m(f m s 10), f m s 14, f m s 17$ and $f m s 13$ genes were present in all isolates tested, while fms 15 was present in all but one. Among the endocarditis isolates included in this analysis, the multilocus sequence type 18 (ST18) isolate TX0068, belonging to the global epidemic hospital-associated clonal complex CC17 (Leavis et al., 2003), had all 15 genes, as did the sequenced ST18 isolate TX0016. Another endocarditis isolate, TX2535 (ST17), which also belongs to CC17, lacked fms18. A fourth endocarditis isolate, TX0074 (non-CC17, ST337), had 14 genes and lacked fms20. Thus, our results indicate broad but variable distribution of MSCRAMM-encoding genes in clinical isolates, consistent with a recent study of 22 E. faecium CWA-protein-encoding genes in which four of the genes, fms11-19-16 (orf903-905907) and $f m s 18$ (orf2430) were shown to be specifically enriched in CC17 isolates, while the remaining nine genes were considered to be widespread in both CC17 and nonCC17 nosocomial isolates (Hendrickx et al., 2007). Notably, our preliminary data from screening for $\mathrm{scm}$ in several hundred E. faecium isolates belonging to clinical and nonclinical groups indicate that $\mathrm{scm}$ is absent only rarely from clinical isolates but is frequently absent from stool isolates (S. R. Nallapareddy, J. Sillanpää and B. E. Murray, unpublished data).

In summary, this study identified genes for 14 new $E$. faecium CWA proteins with MSCRAMM-like features. We characterized the function of one of these proteins, $\mathrm{Scm}$, and demonstrated that it is a second collagen-binding protein for E. faecium with specificity for CV. We further showed that the identified minimal ligand-binding region has a $\beta$-sheetrich secondary structure composition characteristic of the A-domains of MSCRAMMs. Scm was shown to be expressed on the surface of many E. faecium clinical isolates during in vitro growth. Eleven of the 14 MSCRAMM-like proteinencoding genes were clustered in four loci, and nine are predicted to encode the components needed to form multiple, distinct, pilus-like structures. We characterized one of these clusters $\left(e b p A B C_{f m}-b p s_{f m}\right)$ and showed that the four genes of this cluster are expressed in TX0082 as two transcripts, $e b p A B C_{f m}$ and $b p s_{f m}$. Subsequent detection of an HMM ladder pattern with anti-EbpC $\mathrm{Cm}_{\mathrm{fm}}$ in Western blots of cell surface extracts from TX0082 provides experimental evidence for the assembly of $\mathrm{EbpC}_{\mathrm{fm}}$ into polymeric structures, such as pili. Our hybridization results for all 14 genes indicate a broad distribution of MSCRAMM- and pilus-encoding genes among clinical isolates; a future study will assess their distribution in natural E. faecium populations from a variety of sources. The ability of E. faecium to produce two surface-anchored collagen adhesins with different collagen type specificities, and the common occurrence of the scm gene as well as the 13 other newly identified MSCRAMM- and pilus-encoding genes among clinical E. faecium isolates, may have important implications for colonization and infection by this opportunistic pathogen.

\section{ACKNOWLEDGEMENTS}

This work was supported in part by NIH grant R01 AI067861 from the Division of Microbiology and Infectious Diseases, National Institute of Allergy and Infectious Diseases (NIAID) to B. E. M. Additional support for this work is funded by NIH grant R01 AI20624 from the NIAID to M. H.

\section{REFERENCES}

Arduino, R. C., Murray, B. E. \& Rakita, R. M. (1994). Roles of antibodies and complement in phagocytic killing of enterococci. Infect Immun 62, 987-993.

Barocchi, M. A., Ries, J., Zogaj, X., Hemsley, C., Albiger, B., Kanth, A., Dahlberg, S., Fernebro, J., Moschioni, M. \& other authors (2006). A pneumococcal pilus influences virulence and host inflammatory responses. Proc Natl Acad Sci U S A 103, 2857-2862.

Bowden, M. G., Chen, W., Singvall, J., Xu, Y., Peacock, S. J., Valtulina, V., Speziale, P. \& Höök, M. (2005). Identification and preliminary characterization of cell-wall-anchored proteins of Staphylococcus epidermidis. Microbiology 151, 1453-1464.

Coque, T. M., Patterson, J. E., Steckelberg, J. M. \& Murray, B. E. (1995). Incidence of hemolysin, gelatinase, and aggregation substance among enterococci isolated from patients with endocarditis and other infections and from feces of hospitalized and community-based persons. J Infect Dis 171, 1223-1229.

Deivanayagam, C. C., Wann, E. R., Chen, W., Carson, M., Rajashankar, K. R., Höök, M. \& Narayana, S. V. (2002). A novel variant of the immunoglobulin fold in surface adhesins of Staphylococcus aureus: crystal structure of the fibrinogen-binding MSCRAMM, clumping factor A. EMBO J 21, 6660-6672.

Dramsi, S., Trieu-Cuot, P. \& Bierne, H. (2005). Sorting sortases: a nomenclature proposal for the various sortases of Gram-positive bacteria. Res Microbiol 156, 289-297.

Dramsi, S., Caliot, E., Bonne, I., Guadagnini, S., Prevost, M. C., Kojadinovic, M., Lalioui, L., Poyart, C. \& Trieu-Cuot, P. (2006). Assembly and role of pili in group B streptococci. Mol Microbiol 60, 1401-1413.

Hendrickx, A. P., van Wamel, W. J., Posthuma, G., Bonten, M. J. \& Willems, R. J. (2007). Five genes encoding surface-exposed LPXTG proteins are enriched in hospital-adapted Enterococcus faecium clonal complex 17 isolates. J Bacteriol 189, 8321-8332.

Kang, H. J., Coulibaly, F., Clow, F., Proft, T. \& Baker, E. N. (2007). Stabilizing isopeptide bonds revealed in Gram-positive bacterial pilus structure. Science 318, 1625-1628.

Kemp, K. D., Singh, K. V., Nallapareddy, S. R. \& Murray, B. E. (2007). Relative contributions of Enterococcus faecalis OG1RF sortase- 
encoding genes, srtA and bps ( $s r t C)$, to biofilm formation and a murine model of urinary tract infection. Infect Immun 75, 5399-5404.

Krishnan, V., Gaspar, A. H., Ye, N., Mandlik, A., Ton-That, H. \& Narayana, S. V. (2007). An IgG-like domain in the minor pilin GBS52 of Streptococcus agalactiae mediates lung epithelial cell adhesion. Structure 15, 893-903.

Leavis, H. L., Willems, R. J., Top, J., Spalburg, E., Mascini, E. M., Fluit, A. C., Hoepelman, A., de Neeling, A. J. \& Bonten, M. J. (2003). Epidemic and nonepidemic multidrug-resistant Enterococcus faecium. Emerg Infect Dis 9, 1108-1115.

Liang, R., Woo, S. L., Takakura, Y., Moon, D. K., Jia, F. \& Abramowitch, S. D. (2006). Long-term effects of porcine small intestine submucosa on the healing of medial collateral ligament: a functional tissue engineering study. J Orthop Res 24, 811-819.

Liu, Q., Ponnuraj, K., Xu, Y., Ganesh, V. K., Sillanpää, J., Murray, B. E., Narayana, S. V. \& Höök, M. (2007). The Enterococcus faecalis MSCRAMM ACE binds its ligand by the collagen hug model. $J$ Biol Chem 282, 19629-19637.

Lobley, A., Whitmore, L. \& Wallace, B. A. (2002). DICHROWEB: an interactive website for the analysis of protein secondary structure from circular dichroism spectra. Bioinformatics 18, 211-212.

Mandlik, A., Swierczynski, A., Das, A. \& Ton-That, H. (2007). Corynebacterium diphtheriae employs specific minor pilins to target human pharyngeal epithelial cells. Mol Microbiol 64, 111-124.

Marraffini, L. A., Dedent, A. C. \& Schneewind, O. (2006). Sortases and the art of anchoring proteins to the envelopes of Gram-positive bacteria. Microbiol Mol Biol Rev 70, 192-221.

Mora, M., Bensi, G., Capo, S., Falugi, F., Zingaretti, C., Manetti, A. G., Maggi, T., Taddei, A. R., Grandi, G. \& Telford, J. L. (2005). Group A Streptococcus produce pilus-like structures containing protective antigens and Lancefield T antigens. Proc Natl Acad Sci U S A 102, 15641-15646.

Murray, B. E. (2000). Vancomycin-resistant enterococcal infections. $N$ Engl J Med 342, 710-721.

Murray, B. E., Singh, K. V., Ross, R. P., Heath, J. D., Dunny, G. M. \& Weinstock, G. M. (1993). Generation of restriction map of Enterococcus faecalis OG1 and investigation of growth requirements and regions encoding biosynthetic function. $J$ Bacteriol 175, 52165223 .

Nallapareddy, S. R., Qin, X., Weinstock, G. M., Höök, M. \& Murray, B. E. (2000). Enterococcus faecalis adhesin, Ace, mediates attachment to extracellular matrix proteins collagen type IV and laminin as well as collagen type I. Infect Immun 68, 5218-5224.

Nallapareddy, S. R., Weinstock, G. M. \& Murray, B. E. (2003). Clinical isolates of Enterococcus faecium exhibit strain-specific collagen binding mediated by Acm, a new member of the MSCRAMM family. Mol Microbiol 47, 1733-1747.

Nallapareddy, S. R., Singh, K. V., Sillanpää, J., Garsin, D. A., Höök, M., Erlandsen, S. L. \& Murray, B. E. (2006). Endocarditis and biofilmassociated pili of Enterococcus faecalis. J Clin Invest 116, 2799-2807.

Nallapareddy, S. R., Sillanpää, J., Ganesh, V. K., Höök, M. \& Murray, B. E. (2007). Inhibition of Enterococcus faecium adherence to collagen by antibodies against high-affinity binding subdomains of Acm. Infect Immun 75, 3192-3196.

Nallapareddy, S. R., Singh, K. V. \& Murray, B. E. (2008a). Contribution of the collagen adhesin, Acm, to pathogenesis of Enterococcus faecium in experimental endocarditis. Infect Immun $\mathbf{7 6}$, $4120-4128$.

Nallapareddy, S. R., Singh, K. V., Okhuysen, P. C. \& Murray, B. E (2008b). A functional collagen adhesin gene, $a c m$, in clinical isolates of Enterococcus faecium correlates with the recent success of this emerging nosocomial pathogen. Infect Immun 76, 4110-4119.
Nicholls, A. C., Oliver, J. E., McCarron, S., Harrison, J. B., Greenspan, D. S. \& Pope, F. M. (1996). An exon skipping mutation of a type V collagen gene (COL5A1) in Ehlers-Danlos syndrome. J Med Genet 33, 940-946.

Patti, J. M., Allen, B. L., McGavin, M. J. \& Höök, M. (1994). MSCRAMM-mediated adherence of microorganisms to host tissues. Annu Rev Microbiol 48, 585-617.

Perkins, S., Walsh, E. J., Deivanayagam, C. C., Narayana, S. V., Foster, T. J. \& Höök, M. (2001). Structural organization of the fibrinogen-binding region of the clumping factor B MSCRAMM of Staphylococcus aureus. J Biol Chem 276, 44721-44728.

Pizarro-Cerda, J. \& Cossart, P. (2006). Bacterial adhesion and entry into host cells. Cell 124, 715-727.

Ponnuraj, K., Bowden, M. G., Davis, S., Gurusiddappa, S., Moore, D., Choe, D., Xu, Y., Hook, M. \& Narayana, S. V. (2003). A 'dock, lock, and latch' structural model for a staphylococcal adhesin binding to fibrinogen. Cell 115, 217-228.

Rakita, R. M., Quan, V. C., Jacques-Palaz, K., Singh, K. V., Arduino, R. C., Mee, M. \& Murray, B. E. (2000). Specific antibody promotes opsonization and PMN-mediated killing of phagocytosis-resistant Enterococcus faecium. FEMS Immunol Med Microbiol 28, 291-299.

Rice, L. B. (2001). Emergence of vancomycin-resistant enterococci. Emerg Infect Dis 7, 183-187.

Rice, L. B., Carias, L., Rudin, S., Vael, C., Goossens, H., Konstabel, C., Klare, I., Nallapareddy, S. R., Huang, W. \& Murray, B. E. (2003). A potential virulence gene, $h y l_{E f m}$, predominates in Enterococcus faecium of clinical origin. J Infect Dis 187, 508-512.

Rich, R. L., Kreikemeyer, B., Owens, R. T., LaBrenz, S., Narayana, S. V., Weinstock, G. M., Murray, B. E. \& Höök, M. (1999). Ace is a collagen-binding MSCRAMM from Enterococcus faecalis. J Biol Chem 274, 26939-26945.

Roche, F. M., Massey, R., Peacock, S. J., Day, N. P., Visai, L. Speziale, P., Lam, A., Pallen, M. \& Foster, T. J. (2003). Characterization of novel LPXTG-containing proteins of Staphylococcus aureus identified from genome sequences. Microbiology 149, 643-654.

Scott, J. R. \& Zahner, D. (2006). Pili with strong attachments: Grampositive bacteria do it differently. Mol Microbiol 62, 320-330.

Sillanpää, J., Xu, Y., Nallapareddy, S. R., Murray, B. E. \& Höök, M. (2004). A family of putative MSCRAMMs from Enterococcus faecalis. Microbiology 150, 2069-2078.

Singh, K. V., Coque, T. M., Weinstock, G. M. \& Murray, B. E. (1998). In vivo testing of an Enterococcus faecalis efaA mutant and use of efaA homologs for species identification. FEMS Immunol Med Microbiol 21, 323-331.

Singh, K. V., Nallapareddy, S. R. \& Murray, B. E. (2007). Importance of the ebp (endocarditis- and biofilm-associated pilus) locus in the pathogenesis of Enterococcus faecalis ascending urinary tract infection. J Infect Dis 195, 1671-1677.

Telford, J. L., Barocchi, M. A., Margarit, I., Rappuoli, R. \& Grandi, G. (2006). Pili in Gram-positive pathogens. Nat Rev Microbiol 4, 509-519.

Teng, F., Kawalec, M., Weinstock, G. M., Hryniewicz, W. \& Murray, B. E. (2003). An Enterococcus faecium secreted antigen, SagA, exhibits broad-spectrum binding to extracellular matrix proteins and appears essential for E. faecium growth. Infect Immun 71, 5033-5041.

Ton-That, H. \& Schneewind, O. (2003). Assembly of pili on the surface of Corynebacterium diphtheriae. Mol Microbiol 50, 1429 1438.

Ton-That, H., Marraffini, L. A. \& Schneewind, O. (2004). Sortases and pilin elements involved in pilus assembly of Corynebacterium diphtheriae. Mol Microbiol 53, 251-261. 
Wenstrup, R. J., Florer, J. B., Brunskill, E. W., Bell, S. M., Chervoneva, I. \& Birk, D. E. (2004). Type V collagen controls the initiation of collagen fibril assembly. J Biol Chem 279, 53331-53337.

Whitmore, L. \& Wallace, B. A. (2004). DICHROWEB, an online server for protein secondary structure analyses from circular dichroism spectroscopic data. Nucleic Acids Res 32, W668-W673.

Willems, R. J., Homan, W., Top, J., van Santen-Verheuvel, M., Tribe, D., Manzioros, X., Gaillard, C., Vandenbroucke-Grauls, C. M., Mascini, E. M. \& other authors (2001). Variant esp gene as a marker of a distinct genetic lineage of vancomycinresistant Enterococcus faecium spreading in hospitals. Lancet 357, 853-855.
Wilson, K. (1994). Preparation of genomic DNA from bacteria. In Current Protocols in Molecular Biology, pp. 2.4.1-2.4.2. Edited by F. M. Ausubel, R. Brent, R. E. Kingston, D. M. David, J. G. Scidman, J. A. Smith \& K. Struhl. Brooklyn, NY: Green Publishing Associates.

Xu, Y., Liang, X., Chen, Y., Koehler, T. M. \& Höök, M. (2004). Identification and biochemical characterization of two novel collagen binding MSCRAMMs of Bacillus anthracis. J Biol Chem 279, 51760-51768.

Zong, Y., Xu, Y., Liang, X., Keene, D. R., Höök, A., Gurusiddappa, S., Höök, M. \& Narayana, S. V. (2005). A 'collagen hug' model for Staphylococcus aureus CNA binding to collagen. EMBO J 24, 4224-4236.

Edited by: K. E. Weaver 